\title{
Financing a PPP Project: Sources and Financial Instruments-Case Study from China
}

\author{
Nguyen Ngoc Linh ${ }^{1}$, Xiao Wan ${ }^{1} \&$ Hoang Thi Thuy ${ }^{1}$ \\ ${ }^{1}$ School of Business Administration, South China University of Technology, Guangzhou, China \\ Correspondence: Nguyen Ngoc Linh, School of Business Administration, South China University of Technology, \\ Guangzhou, China. E-mail: 3023249352@qq.com
}

Received: July 9, 2018

doi:10.5539/ijbm.v13n10p240
Accepted: August 29, 2018

Online Published: September 27, 2018

URL: https://doi.org/10.5539/ijbm.v13n10p240

\begin{abstract}
The Public-Private Partnership (PPP) model is often referred to as a new effective way in funding issue solving for infrastructure development and management. A PPP model project involves numerous of stakeholders and the most typical and basic PPP model comprised of three actors: Government, the private sector and financial institutions. Based on the features of PPPs, the differences between PPP model and traditional financing methods are clearly demonstrated through the financing period; investment and financing subject; property ownership; financing credit basis; financing purposes; source of repayment; guarantee; and degree of financing risk.

On the other hand, the selection of a suitable structure from the financial source is based on the choice of the best combination of equity and debt. In terms of project financing structure, it can be divided into three main sections: equity contributions, debt contributions and mezzanine/Subordinated contributions. Moreover, according to the characteristics of different PPPs, the financial structure of the project will be determined to optimize the financial benefits of the project. Furthermore, for each stage of the project, financial instruments will be used appropriately.

This paper will deliver a summary and review of PPP projects, as well as the stakeholders involved in implementing a project under a basic PPP model. In addition, this paper will discuss the financial structure of a project, and the PPP project financial instruments that commonly used will also be clearly analyzed. Based on the in-depth knowledge of the PPP model, the paper will depend on the development situation of the PPP model in some countries, especially China, to provide visual examples of each financial instrument.
\end{abstract}

Keywords: public-private partnership, financing PPP project, financing source, financial instruments

\section{Introduction}

The Public-Private Partnership (PPP) model is often referred to as a new effective way in funding issue solving for infrastructure development and management. Since the 1990s, government sectors were keen to seize opportunities for the private sector to participate in supporting the development of related infrastructure and public services within the PPPs framework (Richard, 2008). In 1992, the first Foreign Portfolio Investment (FPI) was proposed, encouraging the private sector and the public sector to establish cooperation to form a joint venture. In accordance with the provisions of the joint venture agreement to provide real estate services, public service management (Yescombe, 2007). PFI is considered the most classic model of PPP in the UK. After that, countries around the world started to have specific definitions of the PPP model and implemented projects that applied this model framework.

In the first half of 2017, Indonesia was the country had the highest amount of PPI investment in the world, while Pakistan and Jordan were new entrants to the top five highest PPI-investment countries, joining Indonesia, Brazil, and China (Note 1). In China, along with the popularity and development of the PPP project, although difficult, still achieved significant results. Based on identifying non-governmental objects as "social capital" instead of "private capital" as pioneers, the Chinese government has opened up opportunities for state-owned enterprises to participate in the PPP project. Shajiao B power plant in Shenzhen is a BOT project that came into operation in 1988, and has been known as the first PPP model in China. From the year 1990 to the end of Q3 2017, the number of infrastructure projects that are under construction or operating in whole of China reached to 1414 projects, of which the underground rate is $35.2 \%$ (Note 2), and total investment at US\$ 16.8 million (Note 3). 


\section{Public-Private Partnership Projects (PPPs)}

\subsection{Overview PPP Model}

PPPs are a long-term contracting mechanism (appreciate 10-50 years) between the public sector (maybe national, state, provincial, or local level) and private (non-State) sector, in order to provide public services, which are traditionally provided only by the public sector (Yescombe, 2007). PPP model covers the construction and maintenance of government infrastructure assets, as well as management of existing assets, for example schools, hospitals, bridges.

Through the PPP model, the skills, assets and financial resources of both public and private sector are distributed in a complementary way with risks and benefits shared, to bring about optimal service delivery and good value to citizens, in which the rights and responsibilities are also allocated correspondingly to each party's participation (Darrin \& Mervyn, 2004). It means during the implementation of the project, the public sector does not take all responsibility, but it will be partly transferred to the private sector.

In addition, the relationship between the public sector and the private sector can be understood on the basis of risks and benefits shared. Private sector pursues economic and social benefits, while governments need to improve investment efficiency, and improve service user satisfaction (Pu Ming Shu et al., 2016). Furthermore, the public sector takes private sector's resources, to aim at investment in infrastructure and finance, design, construction and operation to maintain all or part of the project (Hart \& Moore, 2014). Private sector's participation offers the potential to increase efficiency in investment and new technology, providing innovative solutions. This often results in improving management, raising transparency and enhancing quality and cost efficiencies (Savas, 2000). Additionally, the government can mobilize capital from the private sector through the PPP model, to boost investment, manage costs better, to improve the efficiency of the use of resources throughout the life cycle of the asset (Yescombe, 2007).

Apart from that, (PPP Sub-Group, 2004), (Forward \& Aldis, 2009), (Kappeler \& Nemoz, 2010) all agreed that risk sharing was a central issue and it was a feature of the PPP model, which included construction risk, market risk, financial risks (exchange rate changes, interest rates, etc.), operating risk, legal risk... The purpose of risk transfer and risk sharing in PPPs is allocating risk to the party which is best equipped to manage it (Davies P. et al, 2005; OECD, 2008). Besides, PPP model focuses on output standards, encourages private sector in contributing subjective ideas to reduce costs, increase effectiveness in project implementation.

\subsection{Basic characteristics in PPP model}

A PPP model project involves numerous of stakeholders and it is understood as a complex network of multi-stakeholder relationships and their formal relationships are defined by contracts. The most typical and basic PPP model comprised of three actors: The government, the private sector (for which China is replaced by "social capital") and financial institutions.

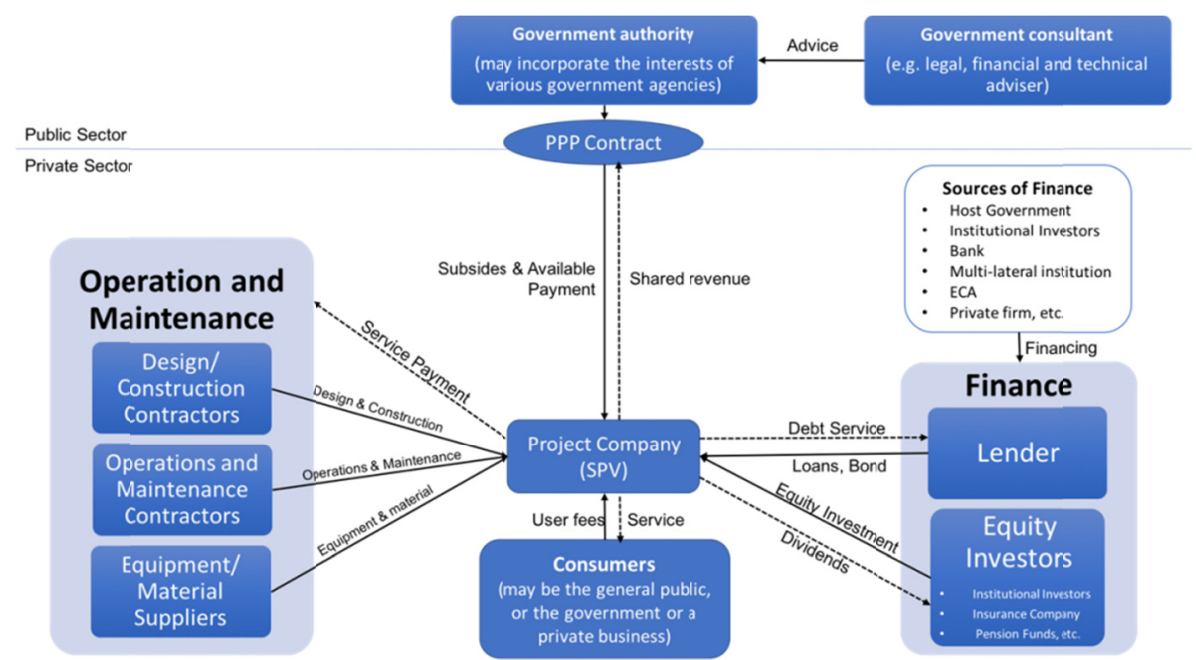

Figure 1. Principal parties in a typical PPP project structure

Typically, the public sector plays a role in the PPP model as the initiator, proponent, and often not, the core actor in raising funds for the project. In the process of project development and implementation, the public sector 
plays three roles: guiding investment, supervising public affairs and purchasing public products/services (or the agent of the purchaser of public products/services).

Next, the private sector is the subject of PPPs and is also the actual investment characteristic in PPPs. In the process of developing PPPs, the private sector does not directly embark, but together with government, (or public authorities) jointly form one entity, known as "project company", which is in charge of design, capital mobilization, construction and operation. The project company in the PPP model is a limited liability company, called the Special Purpose Vehicle (SPV), in some articles called "the concession company". Figure 1 shows how the project company (SPV) interrelated with various parties in PPPs. SPV is created to facilitate financial transactions, establish rules and regulations, control management, and concurrently sign contracts between the involved parties (Marsillo \& Vecchi, 2004).

The third characteristic in PPP model is financial institutions, including commercial banks, credit institutions, multi-lateral financial institutions (e.g. World Bank, Asian Development Bank) and non-bank financial institutions. Depending on the capital requirements of PPPs, financing institutions may be one or more financial institutions. Table 1 below shows the difference between PPP funding and traditional financing method.

Table 1. Comparing PPP financing method and traditional financing method.

\begin{tabular}{|c|c|c|}
\hline Sectors & PPP model & Traditional financing method \\
\hline Financing period & Often more than 10 years & General within 10 years \\
\hline Investment subject & Diversity & Relatively single \\
\hline Property ownership & No prosecution right or limited prosecution right & Full prosecution right \\
\hline Financing credit basis & $\begin{array}{l}\text { Except a few of property are formed from the } \\
\text { capital of the project that the project company has } \\
\text { the right to prosecute, financing credit basis can } \\
\text { only be referenced by credit profile of government } \\
\text { and private sector, economic value, asset } \\
\text { evaluation and future earnings of PPPs. }\end{array}$ & $\begin{array}{l}\text { Depending on company's credit profile, signed } \\
\text { contracts and agreements, asset status (e.g. value } \\
\text { of total accumulated assets, net assets), Financial } \\
\text { situation (e.g. business performance), payment } \\
\text { capacity and payment intentions, as well as } \\
\text { guarantees... }\end{array}$ \\
\hline Financing purposes & $\begin{array}{l}\text { Financing capital can only be used for project } \\
\text { needs (usually used to supplement project capital } \\
\text { for the project company, engineering construction } \\
\text { funds and supporting working capital required for } \\
\text { project construction), cannot be used for other } \\
\text { purposes. }\end{array}$ & $\begin{array}{l}\text { Mainly for the company's assets, business needs, } \\
\text { and sometimes for specific project construction, } \\
\text { but it is closely related to the company's own } \\
\text { operations. }\end{array}$ \\
\hline Source of repayment & $\begin{array}{l}\text { Project income (in which cash flow is through } \\
\text { operational prerogative, right to charge, or user } \\
\text { fee, or service fees payment of government, or } \\
\text { both (user payment }+ \text { feasibility gap subsidy). }\end{array}$ & $\begin{array}{l}\text { All assets and income of the company } \\
\text { (Including all income, such as project } \\
\text { construction and operating income, sales revenue, } \\
\text { operating income, and other company's income, } \\
\text { disposable current assets). }\end{array}$ \\
\hline Guarantee & $\begin{array}{l}\text {-More complex legal guarantee structure system. } \\
\text {-There is no particularly strong guarantee; } \\
\text { sufficient value, or effective collateral mortgage. }\end{array}$ & $\begin{array}{l}\text {-The guarantee structure is relatively simple. } \\
\text {-Effective, full-value asset collateral or third-party } \\
\text { guarantee. }\end{array}$ \\
\hline
\end{tabular}

\section{Sources of Fund}

The main motivation for the government to consider projects PPP models is the ability to bring in new sources to finance public infrastructures and services. According to Weber and Alfen, project financing refers to the financing of a particular, clearly definable economic unit (project) in which mainly depends on the project cash flow. The key characteristics in financing a PPP project includes project company (SPV); cash flow-based lending; risk sharing structure; limitation of liability; and off-balance sheet finance (Weber \& Alfen, 2010). In fact, the capital of a PPP project comes from a variety of sources, such as cash from local governments or project proponents, bank insurance, bonds from the capital market, investment resources from the district private sector, etc. Besides that, PPPs require extremely strict about financial aspect, as well as the project's financial structure building on the basis of the cost of their acquisition and maintenance is as small as possible, respecting all the limiting conditions. 
In the case of PPPs, the selection of an optimal structure from the financial source is based on the choice of the best combination of Equity-provided by project company's shareholders and Debt-provided by project company's lenders.

In terms of project financing structure, it can be divided into three main sections: Equity contributions, Debt contributions and Mezzanine/Subordinated contributions.

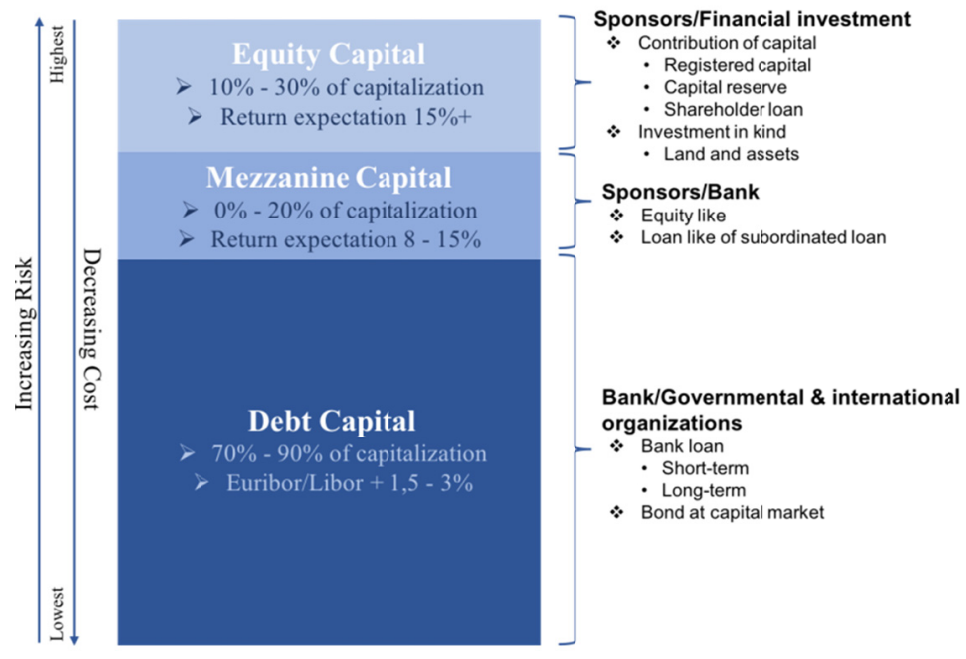

Figure 2. Financial structure of PPP Projects and return profile of capitall types

\subsection{Equity Capital}

Equity capital in financing projects is the basic foundation for subsequent financing of the project company. Equity contributors can include the government agencies that initiated the project (local governments, franchisees, etc.); the project participants; the local investors; the granters (contractors and subcontractors, professional operators, raw material suppliers, etc.), other government agencies, institutional investors and bilateral or multilateral organizations... becomes shareholders of the project company (SPV). As a result, sponsor funding is generally through equity contributions in SPV through share capital and other shareholder funds (Yescombe, 2007). In this case, SPV plays the role of design builder, operator and project manager. At the same time, the shareholders of the SPV also asked to sign the shareholders' agreements, such as Preconditions; Establishment and financing of project company; Business scope of project company; Shareholder rights; Shareholder commitment to perform the PPP project contract; Composition and terms of reference of the board of supervisors... (Note 4). Otherwise, with financial structure of company project, in order to protect the interests of both shareholders and lenders, the proportion of equity investment normally equates to $10 \% \sim 30 \%$ of total project investment.

Because the PPP project has huge capital demand, a private enterprise will not be able to provide the necessary funds, thus it requires a number of financial firms to invest and lend money. On the other hand, as described in Farquharson's chapter on PPP financing (Edward Farquharson et al., 2011), the equity investment is "first in, last out". Specifically, if the project has any losses, the losses are borne first by the equity investors, while the lenders begin to suffer only if the equity investment is lost. Consequently, equity providers require a rate of return target, which is higher than the interest rate of debt financing, with purpose to compensate the higher risk that they incur because they have a basis for asking to income and assets of the project. Furthermore, equity capital is a long-term investment and not reverse. It means when investors want to recover capital, the only way is to sell the shares they are holding through financial markets (Feng, 2017).

In the case of project planning in China, Government is usually the project proposal, and provides good faith payment. Social capital establishes a project company, simultaneously holds shares in the project. Government can buy shares of the project company (Note 5), with a stock ownership percentage of no more than $50 \%$ (Note 6). Moreover, infrastructure projects often require the equity capital proportion which is not less than $20 \%$ of total investment, for example with urban and transport infrastructure projects, percentage of equity capital in the urban rail transit project is $20 \%$; in the port, coastal and inland shipping and airport projects is $25 \%$; and in Railway and highway is $20 \%$ (Note 7 ). 


\subsection{Debt Capital}

As noted above, besides equity contribution, capital mobilization by debt is also an important key contributor to the success of PPP projects, through external loans to increase capital. PPPs use external debt to raise capital and are usually financed by combining equity and debt dependent on a suitable equity-to-debt ratio (Akintoye \& Beck, 2009). Generally, debt contribution accounts for a large proportion of the investment demand (typically 70-90\%) in PPP projects (ESCAP, 2008), some PPP project even have debt financing reaches 100\% (Daube, Vollrath \& Alfen, 2008). Next, lenders for PPP projects developing countries, such as China, relatively diverse. Some of the major lenders may include commercial banks, multilateral and bilateral development banks and finance institutions, export credit agencies bondholders, and sometimes the host country government...

Because project finance is defined as an independent capital investment, in which the sponsors are separated from project company's assets and general-purpose obligations. In other words, lenders rely on the cash flow of the project itself to repay the loan and pay interest rather than the singular performance of an individual asset or investment (known as debt service), known in some academic papers as limited recourse or non-recourse project finance. Further defining these two terms, the project company as a borrower, which is established without its own credit profile history, lenders must focus on the cash flow of the project for repayment, instead of relying on sponsors' credit support or the value of the assets of the relevant facilities of the project (Comer, 1996).

Alternatively, although equity contributions face the highest risk, earning the highest return, however, equity contributors hold the lowest priority when raising funds for PPP project, while debt funds have the highest priority. Therefore, the lender will have right to project assets and revenues before the equity contributors can obtain any return, any repayment... (World Bank Group, 2016). In addition, lenders may require a bank guarantee or third-party on equity payments to ensure that the loan is paid on time.

Instruments when mobilizing capital by debt contribution are often used: financial institutions/ bank loans, bond or bond project; asset-based security... Bank loans are the most common and the main source of funds for PPP projects. In addition, during the construction process, the project company may issue corporate bonds, project bonds, medium term notes, etc. for debt financing. When the project goes into operation, the project company can issue asset-based security for refinancing.

\subsection{Mezzanine/Subordinated Capital}

According to definition of OECD, mezzanine capital is seen as a layer located between equity and debt, which can fill the gap of two above kinds (OECD, 2015). It is treated as equity on project company's balance sheet. As such, lenders are offered the rights and benefits liked project company's shareholders in case of default, after venture capital corporation and other senior lenders are paid. In addition, using mezzanine financing also allows the project company to maintain a greater overall level of leverage, although the cost is higher than premium debt (typically $20-30 \%$, and this ratio is fixed). Besides that, it also includes the advantages of two above contribution ways, such as deducting tax; providing long-term investment capital; being in principle unsecured (Ganatra et al., 2014). On the other hand, security and other rights tend to be managed through trust agreements with a lender or third-party representative for the lender.

Financing PPPs through Mezzanine capital is obtained from shareholders, institutional sponsors, commercial banks, bilateral and multilateral organizations (World Bank Group, 2016). According to Ganatra et al. (2014), financial instruments of this kind contribution includes participating loans; subordinated loan; "silent" participations; convertible bonds; option bonds and preferred stocks. Frank (2004) differentiated a subordinated debt, convertible subordinated debt and a redeemable preferred equity.

\section{Financial Instruments}

Based on the basis of project financing through two types of funding sources: Equity and Debt, and combined with the investment phases: first stage and refinancing, a number of financial instruments for PPP projects are listed (Table 2), classified and arranged into appropriate financial phases. 
Table 2. Some financial instruments for PPP projects

\begin{tabular}{|c|c|c|c|c|c|}
\hline \multirow[b]{2}{*}{ Financing instruments } & & \multicolumn{2}{|c|}{ Type of financing } & \multicolumn{2}{|c|}{ Financing phase } \\
\hline & & $\begin{array}{l}\text { Equity } \\
\text { capital }\end{array}$ & $\begin{array}{l}\text { Debt } \\
\text { capital }\end{array}$ & $\begin{array}{l}\text { First } \\
\text { stage }\end{array}$ & Refinancing \\
\hline $\begin{array}{l}\text { Government/ } \\
\text { Project sponsors; }\end{array}$ & Guidance fund & $\checkmark$ & $x$ & $\checkmark$ & $x$ \\
\hline \multirow{2}{*}{ Commercial bank } & Bank loans & $x$ & $\checkmark$ & $\checkmark$ & $\checkmark$ \\
\hline & Commercial paper, medium term note; PPN & $x$ & $\checkmark$ & $x$ & $\checkmark$ \\
\hline \multirow[t]{2}{*}{ Insurance } & $\begin{array}{l}\text { Insurance funds (through capital management } \\
\text { plan) }\end{array}$ & $\checkmark$ & $\checkmark$ & $\checkmark$ & $\checkmark$ \\
\hline & Insurance own funds (direct investment) & $\checkmark$ & $x$ & $x$ & $\checkmark$ \\
\hline \multirow{5}{*}{ Securities } & Corporate bond & $x$ & $\checkmark$ & $x$ & $\checkmark$ \\
\hline & IPO & $\checkmark$ & $x$ & $x$ & $\checkmark$ \\
\hline & Project revenue bond & $x$ & $\checkmark$ & $x$ & $\checkmark$ \\
\hline & ABS & $x$ & $\checkmark$ & $x$ & $\checkmark$ \\
\hline & M\&A restructure & $\checkmark$ & $x$ & $x$ & $\checkmark$ \\
\hline \multirow{3}{*}{$\begin{array}{l}\text { Asset } \\
\text { agency }\end{array}$} & Trust plan & $\checkmark$ & $\checkmark$ & $\checkmark$ & $\checkmark$ \\
\hline & Real estate brokerage management & $\checkmark$ & $\checkmark$ & $\checkmark$ & $\checkmark$ \\
\hline & Insurance capital management plan & $\checkmark$ & $\checkmark$ & $\checkmark$ & $\checkmark$ \\
\hline Other & Financing lease & $x$ & $\checkmark$ & $\checkmark$ & $\checkmark$ \\
\hline
\end{tabular}

According to Yescombe (2007), project-finance debt is provided by two major sources-commercial banks and bond investors. In addition, along with the development of the financial market, a number of other funding modalities, such as IPO and ABS, are also widely used and potentially growing. Here are some of the commonly used financial instruments

\subsection{PPP Fund}

PPP funds are also classified into several categories, includes the Government Guidance Fund, Social Capital Launches Investment Funds... And funding period is generally not more than 10 years. PPP guidance fund is the capital invested by local governments, the central government or the project initiating parties to attract investment from financial institutions and outside investors. This investment is usually through the shares of the project company.

\subsection{Initial Public Offering of Capital Markets (IPO)}

For PPP project with the stable future cash flow and abundant resources, PPPs can be linked to the capital market effectively by offering shares to the public. Through financial markets, it represents the public's expectation for a PPP project, thereby obtaining high valuations and profits (Weber \& Alfen, 2010). The advantage of stocks is high liquidity. However, the application of PPP projects into the financial market exits high risky, for example, the stock market crisis can also damage the PPP projects, resulting investors unable to recover capital. On the other hand, the process of complex and expensive reworking.

\subsection{Bank Loans}

Bank plays a pivotal role in financing the PPP project. Capital investment from bank banks is plentiful, optimizing the use of this investment channel will greatly reduce the financial pressure to the government. In addition, banks participate in PPP projects by two mainly ways: first, the bank through fixed assets (collateral) to lend credit; second, the bank issued a number of financial management products such as short-term securities, medium term notes, Private Placement Note (PPN) ... to collect sources of investment from financial institutions, private investors, invest in a PPP project company in the form of shares, funds or debt financing. In fact, borrowing money from banks is still the main channel.

For bank loans, the traditional investment method for facilities can be classified into short-term (less than 1 year), medium-term (1 to 5 years) and long-term (over 5 years). Loan interest rates are typically smaller than the benchmark interest rate (specially in China, the difference is approximate $10 \% \sim 20 \%$, based on the calculation, the loan interest rate over 5 years will be around 4.4\% to 5.9\%) (Note 8). For small-scale PPP loans, individual banks can be solved. For instance, the An Hui Outer Ring Road PPP project, funded by the Ministry of Finance of China, has a total investment of RMB 1.98 billion, a 13-year period (including 2 years of construction). Investment company RMB 500 million in cash, the remaining capital invested by CDB Anhui Branch with a 
loan term of 11 years. The loan interest rate was $4.9 \%$ of the benchmark lending rate of RMB over 5 years. The first loan was completed on August 26, 2015.

On general, PPPs require a large capital base, banks can link together with one or more financial institutions to jointly finance the project (syndicate loans), on the one hand to provide loans for one project. With large investment capital, ensuring the project implementation smoothly, on the one hand, to reduce the financial risks for participating banks. On the other hand, due to the long-term nature and long payback period of the PPP project, banks typically use fixed-rate mortgages loans, working capital loans. The loan term is medium or long term. (the longest loan can be up to 30 years), very suitable for the nature of the PPP project, but apply and use has the certain limited, some smaller and non-focused PPP projects are more difficult to obtain syndicated loans.

\subsection{Bond}

Bond allows the project company to directly access the lender, distinguishing from using the bank for lending as an intermediary. The bond issuers borrow money by issuing bonds in the financial market. After the rating agencies evaluate the project's risk and assign a credit rating to the bonds, bond issuers fully establish the major public offering and issuing firms for public investors, the small offering for qualified investors and the non-public offering system for qualified investors.

Project bonds, which are based on the project's own cash flow, can better meet the direct financing needs of the project company. Project revenue bonds issued by the project implementing entity or the actual controller, and it raised for investment and construction of specific projects, repay the principal and interest of funds fully or mainly from the operation of the project after the completion of bond yields (Note 9). Bonds during the period of legitimate financial subsidies accounted for the proportion of total project revenue shall not exceed $50 \%$. In addition, the limit of bond issuance usually must not exceed $40 \%$ of the net assets of the company.

Project bond issued by project company often face to some barriers when publishing in capital market, because PPPs project company is often newly established, lack of past performance support, and the size of the asset is also limited by the size of the project ( $\mathrm{Pu}$ Ming Shu et al, 2016). Therefore, bond financing liked more appropriate than bank loan when financing PPP project required a considerable investment capital, because of the more liquidity. Comparing with bank loan, some extra key economic advantages of bond financing such as lower refinancing risk, longer maturity (up to 30 years that corresponding with the term of the project's contracted revenues) (Deloitte, 2015) (PwC, 2013), also considered to be less expensive than an equivalent amount of bank loan, partly cause a larger investor base (Yescombe, 2007).

Regarding bond market in some Asia countries as China, it consists of three sub-markets: the interbank market, the foreign exchange market, and the non-commercial market of commercial banks. Major bond issuers may be listed following: Ministry of Finance of China; People's Bank of China; local government; Policy-related banks; commercial banks and other non-bank financial institutions, financial corporations and non-financial corporation and securities companies. Since 2014, apart from credit financing such as government bonds, corporate bonds, medium-term notes..., the Chinese government has also begun to foster the issuance of project revenue bonds as common financing modes for PPP. As a result of the promulgation of the series of supporting documents, China is seeing a growing number of project revenue bonds.

\subsection{Asset-Based Security (ABS)}

Asset-based security (ABS) is a debt marketized instrument, which not only provides refinancing for PPPs, but also has the ability to manage PPP protocol, and the benefit in increasing the property mobility of the PPP project. In particular, the issuances of $\mathrm{ABS}$ request basic assets that satisfied regulatory requirement, specially regulations about legal cooperation and ownership; being able in creating independence and predict future cash flows; as well as concertize the ownership of property or property (Fang, 2010).

In the case of PPP financing, ABS is a financial instrument that bundles contractual debts (usually loans) for the purpose of pooling and selling to investors through the capital market in order to finance PPPs. Investment sources may include commercial banks, wealth management fund, securities investment funds, asset management plan, trust management plan, etc. It provides financial support for the transfer of assets to specialized unit - the project company. The project company sets up a special support plan for property and then, using the cash flow stratification and other structured finance technology aim to assess the credibility of asset backed securities, to achieve the purpose of project finance, use future cash flows as a source of repayment. Project company, which is a separate legal entity from the bank, issue notes for the purpose of repurchasing the debt package from the bank. These notes are rated by credit agencies, then, as stated in the foregoing, are sold on the capital market. As a result, the bank generates liquidity efficiently through third parties, at the same time, 
they also earn a premium when creating the ABS portfolio. In addition, ABS allows the bank to convert infrastructure long-term loans into cash, leads the increasing of lending capacity (Hao B. J., 2017). PPP project that relies on government subsidies or a feasible gap grant as its source of income will belong to the debt-based asset and may also be securitized (Chu Xiao Ling et al., 2017). It worthy notes that ABS creates the ability to transform a group of Non-liquid infrastructure loans becoming tradable securities. And, this transformation also has other dimensions such as credit quality and loan tenor (OECD, 2015).

With sponsors, securitized-debt portfolios bring risk-diversification advantages, and they can access asset classes themselves when they do not directly invest. According to Feng (2017), compared with loans and corporate bonds, ABS can obtain lower financing costs if the project assets are of good quality. In China, depending on the rating, the four single-income issues have been issued 3.7\%-5.2\%.

In December 2016, Chinese Development and Reform Commission Joint Commission released "Notice on Promoting Work Related to Asset Securitization in Government and Social Capital Cooperation (PPP) Projects in the Field of Traditional Infrastructure" (Development and Reform Investment [2016] No. 2698), the asset securitization of PPP projects was officially launched, indicating a new direction for the financing of PPP projects during the operation period. According to Fang W. S. (2010), ABS has become the fastest growing financial instrument, and its followers expand the size of its mayor, the financial costs are also decreasing year by year. In addition, in their study, Chu Xiao Ling et al. (2017) gives a recommendation that in order to reduce the financial cost of ABS products, besides traditional financial instruments such as credit enhancement, the major adjustment by sector to which the project belongs is also a worthwhile consideration. For instance, "low risk" projects can scale up to increase product liquidity and reduce risk premium. Meanwhile, with a steady stream of money in the future, "high risk" projects can reduce the relevance of the issue.

\section{Conclusion}

To conclude, the PPP model is seen as an effective financial channel in solving funding issues for infrastructure and construction management. The selection of financing structures for PPPs needs to be carefully considered based on the credit level of different projects, the need for funding at different stages in each project, as well as its degree of risk. In fact, PPP projects often involve large capital investments along with long life cycles, from the initial planning phase of the project to constructing, and into the operational cycle of up to 20 to 30 years (maybe even 50 years). Besides, the characteristics of cash flow also vary from demand to risk. So, whether it is funding through equity or debt, instead of relying on the credit status of the project investor, it will consider expected income, cash flow level and asset value of PPPs as the basis for deciding the financial structure of the PPP project, and also the appropriate financial resources for each project.

\section{References}

Akintoye, A., \& Beck, M. (2009). Policy, Finance \& Management for Public-Private Partnerships. Wiley-Blackwell.

Chu, X. L., Liu, T., Lu, Z., Wang, S. Q., \& Wu, D. (2017). An Empirical Study on Spread Pricing of PPP Project Asset Securitization Products. Sub National Fiscal Research, 10(13), 13-18.

Comer, B. (1996). Project Finance Teaching Note. The Wharton School.

Darrin, G., \& Lewis, M. K. (2005). Public-Private Partnerships: The Worldwide Revolution in Infrastructure Provision and Project Finance.

Daube, D., Vollrath, S., \& Alfen, H. W. (2008). A comparison of Proẹct Finance and the Forfeiting Model as Financing Forms for PPP Projects in Germany. International Journal of Project Management, 26(4), 376-387.

Davies, P., \& Eustice, K. (2005). Delivering the PPP promise: A review of PPP issues and project. A PriceWaterhouse Coopers Report, 80.

Deloitte. (2015). Project bonds: an alternative source of financing infrastructure projects. Retrieved from $\mathrm{http} / / / \mathrm{www} 2$. deloitte.com/za/en/pages/finance/articles/project-bonds-an-alternative-to-financinginfrastructu re-projects.html

Economic and Social Commission for Asia and the Pacific [ESCAP]. (2008). A Primer to Public-Private $\begin{array}{llll}\text { Partnerships in Infrastructure Development. Retrieved from } & \end{array}$ http://www.unescap.org/ttdw/ppp/ppp_primer/41_sources_of_project_finance.html

Fang, W. S. (2010, September). Application of Project Financing ABS Model and PPP Model in Sustainable Urban Development. Journal of Xiangfan University, 31(9). 
Farquharson, E., Yescombe, E. R., Torres De Mastle, C., \& Encinas, J. (2011). How to engage with the private sector in public-private partnerships in emerging markets (English) (Vol 1). Washington, DC: World Bank.

Feng, Z. J. (2017). Financing strategy of PPP: The structures, Model and Tools of Project-financing. Beijing: Law publishing house.

Frank, R. H. (2004). Roundtable Meeting of Institutional Investors at the 37th Annual Meeting of the Asian Development Bank.

Ganatra, K. A., \& Acharya, P. U. (2014). A glance at the niche market of Mezzanine Finance. Research Journal of Commercial and Behavior Science, 4(2), 7-11.

Hao, B. J. (2017). PPP Project Debt Financing: Financing Instruments.

Hart, O., \& Moore, J. (1991). A Theory of Debt Based on the Inalienability of Human Capital. NBER Working Papers 3906.

Kang, J. (2009). Public-private partnership model features and functions. Economic aspect.

Organization for Economic Co-Operation and Development [OECD]. (2015). Infrastructure financing instruments and incentives.

Price water house Coopers [PwC]. (2013). Capital markets: the rise of non-bank infrastructure project finance. Available at: www.pwc.com/gx/en/capital-projects-infrastructure/publications/assets/ pdfs/

Pu Ming Shu et al. (2016). PPP Project Financial Analysis Application Guide. Beijing: CITIC Publishing Group.

Richard, W. (2008). What is Project finance? Retrieved from http://www.corality.com/tutorials/what-project-finance

Savas, E. (2000). Privatization and Public-Private Partnerships. New York: Seven Bridges Press.

V., M. M. (2004). Project Finance for public investments: The Italian experience.

Weber, B., \& Alfen, H. W. (2010). Infrastructure as an Asset Class - Investment Strategies, Project Finance and PPP. New York: John Wiley and Sons.

World Bank Group. (2016). Sources of Financing and Intercreditor Agreement. Retrieved from https://ppp.worldbank.org/public-private-partnership/financing/sources

Yescombe, E. (2007). Public-Private Partnership-Principle of Policy and Finance. London, UK: Elsevier Ltd.

Notes

Note 1. January - June 2017 Private Participation in Infrastructure (PPI)-Half year update report.

Note 2. Source from Wind database.

Note 3. National PPP Integrated Information Platform Project Library No.8 Quarterly report. Available at http://jrs.mof.gov.cn/ppp/dcyjppp/201710/t20171027_2736578.html

Note 4. "PPP Project Contract Guide" (Trial) - Chinese Ministry of Finance.

Note 5. "Guidelines for the Cooperation model implement of Government and Social Capital" ( Trial) (Cai Jin 2014 - No.113).

Note 6. "Notice of the Ministry of Economic Affairs on Regulating the Administration of Government and Social Capital Cooperation Contracts" (Cai Jin 2014 - No.156) Attached to "PPP Project Cooperation Guidelines (Trial)" Chapter 1, Section I "II. Social Capital Parties".

Note 7. "Circular of the State Council on Adjusting and Improving the Capital System of Fixed Asset Investment Projects". Available at http://www.fae.cn/fg/detail2008993.html

Note 8. 2016 National Social Science Fund Project "Research on private capital gains in China's PPP mode (serial number 16BJY174), 2016 July - 2018 June.

Note 9. "Project proceeds bond management practices".

\section{Copyrights}

Copyright for this article is retained by the author(s), with first publication rights granted to the journal.

This is an open-access article distributed under the terms and conditions of the Creative Commons Attribution license (http://creativecommons.org/licenses/by/4.0/). 